\title{
Analysis of Growth of Intercrop Species in a Maize ( $Z$ ea mays L.)/Cowpea (Vigna unguiculata L. Walp) Intercropping System as Influenced by Crop Arrangement and Proportion in Semi-Arid Nigeria
}

\author{
${ }^{1,2}$ M.A. Adeleke, ${ }^{1,3}$ V.B. Ogunlela and ${ }^{1}$ O.O. Olufajo \\ ${ }^{1}$ Department of Agronomy, Faculty of Agriculture, \\ Institute for Agricultural Research, Ahmadu Bello University, Zaria, Nigeria \\ ${ }^{2}$ Department of Agriculture, Federal Ministry of Agriculture and Rural Development, Abuja, Nigeria \\ ${ }^{3}$ School of Science and Technology, National Open University, Victoria Island, Lagos, Nigeria
}

\begin{abstract}
In order to determine how the growth indices of intercrop species in an intercropping system are influenced by certain factors, field trials were conducted at Institute for Agriculture Research (IAR) farm at Samaru, Zaria during the wet seasons of 2004-2006. The treatments tested consisted of maize and cowpea intercrops with 2 forms of crop arrangement (intra- and inter-row), 4 different crop proportions (1C:1M, $3 \mathrm{C}: 1 \mathrm{M}$, $1 \mathrm{C}: 3 \mathrm{M}$ and $2 \mathrm{C}: 2 \mathrm{M}$ Cowpea: Maize) and 2 row arrangements (single- and paired-row) in factorial combinations. These treatments were arranged in a randomized complete block design with 4 replications. The crop varieties used were: maize-TZPBSR and cowpea-SAMPEA-6. Crop arrangement significantly affected the rate of growth of the 2 component crops. The Relative Growth Rate (RGR) and Crop Growth Rate (CGR) measured at 6-8 and 8-10 Weeks After Sowing (WAS) were higher under the inter-row crop arrangement in maize by 23 and $22.6 \%$, respectively on the average relative to those under the intra-row crop arrangement. The 3:1 and 2:2 (Cowpea: Maize) crop proportions had higher RGR and CGR values. The 3:1 (cowpea: maize) crop proportion in the single row arrangement produced higher growth rates of cowpea than under any of the other arrangements. In relation to the yield parameters which were measured later, the rate of growth in relation to the productivity of maize/cowpea intercropping system could be determined by using the indices of Relative Growth Rate (RGR) and Crop Growth Rate (CGR) particularly at the later stages of growth of the 2 crops. Indices of crop growth were generally higher for the components when they were grown under the single- and inter-row arrangements.
\end{abstract}

Key words: Crop arrangement, crop proportion, growth indices, intercropping, row arrangement, Nigeria

\section{INTRODUCTION}

Every small holder farmer in Africa growing maize/legume intercrop aim at increasing overall yields using limited available labour and capital at his disposal. Greater attention is therefore given by such resource limited farmers to overall stability of yield and income at the expense of sole crop yield per se. The practice of intercropping has over the years helped to reduce variability in total crop biomass, seed production and income due to complementary effects among associated crops (Kumar et al., 1987; Santaella et al., 1999). For these and other reasons intercropping systems are very attractive, not only to smallholder farmers but also to managers of rural development projects in sub-Saharan Africa. Cowpea (Vigna unguiculata L. Walp), the second most important food legume in tropical Africa after common bean (Phaseolus vulgaris) is the most widely cultivated legume crop in Nigeria (Bichi, 1982; Arnon, 1992; Keku, 1999). Due to its beneficial effects on subsequent crops in rotation and intercropping systems, cowpea has always been grown along with other crops, especially with maize, sorghum and millet. It has been reported that although cowpea is a major component of the traditional cropping systems in Africa, Asia and America where it is grown in mixture with other crops in various combinations but for certain reasons, its productivity is low. Such reasons include competition for growth factors such as solar radiation, water and nutrients (Olufajo and Singh, 2002; Moriri et al., 2010).

Studies have been conducted to analyze intercrop radiation interception by plant canopies and its subsequent use. Radiation transfer models for plant canopies were broadly grouped into 2 types; namely, the statistical and geometric methods. Both methods have been used to obtain instantaneous and daily models for

Corresponding Author: V.B. Ogunlela, School of Science and Technology, National Open University, 14/16 Ahmadu Bello Way, Victoria Island, Lagos 
radiation transmission and were validated with a high degree of accuracy through the alternate intercrop canopy. In one of such experiments, Tsubo and Walker (2002) reported that radiation utilization by the intercropping system was equivalent in growth efficiency of maize to sole maize cropping. That is, there was no significant difference in Radiation Utilization Efficiency (RUE) between sole maize and maize intercropped with legumes whereas cowpea had $12.5 \%$ greater radiation-useefficiency in the intercropping arrangement with maize than sole cowpea. In an earlier experiment, a similar result was reported in a millet/groundnut intercropping system where groundnut had a RUE value of $45 \%$ (Keating and Carberry, 1993). The ability of the legumes to utilize radiation efficiently was therefore averred to be responsible for the yield advantage achieved in the intercropping of both cereal and legume crops. The higher LER value obtained from maize/cowpea intercrop, especially when the crop arrangement was inter-row, is as a result of the radiation use efficiency of cowpea and not that of maize (Tsubo and Walker, 2002).

The findings from a recent study by Bedoussac and Justes (2011) re-established the usage of LER as a more reliable index of evaluation along with Crop Growth Rate (CGR). They averred that the outcome of all competitive interactions occurring between 2 crops in an intercropping system can be evaluated using the CGR. While the CGR measures community of crop plants, the Relative Growth Rate (RGR), on the other hand, measures the rate of growth of an individual plant within the environment.

Crop growth rate is generally higher in $\mathrm{C}_{4}$ plant species than in $\mathrm{C}_{3}$ plant species (Tsubo et al., 2004). Maize being a $\mathrm{C}_{4}$ plant compared to cowpea, a $\mathrm{C}_{3}$ plant, grows faster than cowpea. Moreover, maize forms a relatively larger upper canopy structures compared to cowpea and the roots of maize grow into greater and wider area even though of fibrous root system, than those of the beans. Thus, in maize/cowpea intercropping system, maize is generally found to be more competitive than beans (Mukhala et al., 1999; Tsubo et al., 2004). The present study was undertaken with a view to determining the response of growth indices of component crops in a maize/cowpea intercropping system to crop arrangement and proportion.

\section{MATERIALS AND METHODS}

The study was conducted in the wet seasons of 20042006 at the Experimental Farm of the Institute for Agricultural Research (IAR), Ahmadu Bello University,
Samaru (latitude $11^{\circ} 11^{\prime} \mathrm{N}$, longitude $7^{\circ} 38^{\prime} \mathrm{E}$ and $686 \mathrm{~m}$ above sea level), Nigeria. The site is located in the northern Guinea savanna ecological zone of Nigeria. The soil of the experimental site is a well-drained leached ferruginous tropical clay loam.

The treatments consisted of maize and cowpea intercrops with 2 forms of crop arrangement (intra- and inter-row), 4 different crop proportions (1:1, 3:1, 1:3 and 2:2 Cowpea: Maize) and 2 row arrangements (single-row and paired-rows). The treatments were arranged in a factorial combination using randomized complete block design with 4 replications. The crop varieties used were maize TZPBSR (the main crop) and cowpea SAMPEA-6 (the intercrop).

Planting and cultural practices: The experimental site was ploughed, harrowed and ridged $75 \mathrm{~cm}$ apart. The gross plot size was $6 \times 8 \mathrm{~m}$ ( 8 rows, $8 \mathrm{~m}$ long) while the net plot size was $3 \times 8 \mathrm{~m}$ ( 4 rows and $8 \mathrm{~m}$ long). The maize crop was planted as soon as rainfall had established between the end of May and 1st week of June. Maize was sown at an intra-row spacing of $25 \mathrm{~cm}$ with 2 seeds hill ${ }^{-1}$ which was thinned 3 weeks later to 1 seedling hill ${ }^{-1}$. Cowpea was sown by hand at the rate of 2 seeds hill ${ }^{-1}$ in mid-July at $25 \mathrm{~cm}$ apart and later thinned down to 1 seedling hill ${ }^{-1}$.

Measurements: Five plants each of maize and cowpea from each plot were randomly selected and tagged for periodic observation during the crop's growth period. The observations made at $6,8,10$ and 12 weeks after sowing were recorded for maize and 6,8 and 10 weeks after sowing for cowpea. Plant dry weight was determined by random selection of five plants from each plot, cut at the ground level and dried to constant weight in a Gallenkamp oven (model OV-420) at a temperature of $70^{\circ} \mathrm{C}$ and weighed with a Mettler toploading balance (Model P. 1200). The dry weights were used to determine the dry matter accumulation (already presented elsewhere) and subsequently both Crop Growth Rate (CGR) and Relative Growth Rate (RGR). Crop Growth Rate (CGR) which is a measure of the rate of dry matter production per unit of time or dry matter increment per unit area of land per unit of time was computed using the formula described by Radford (1967). Relative Growth Rate (RGR) on the other hand which is the increase in plant material per unit of initial material per unit of time was also computed using the procedure described by Radford (1967).

Statistical analysis: The data collected from the trials were subjected to Analysis of Variance (ANOVA) using the SAS software (SAS, 2001) to determine the significant 
of treatment effects as described by Snedecor and Cochran (1967). The treatment means were then separated using Duncan's Multiple Range Test (DMRT) (Steel et al. 1997).

\section{RESULTS AND DSCUSSION}

Relative growth rate: Table 1 shows the effects of crop arrangement, crop proportion and row arrangement on mean relative growth rate of maize during 6-8 weeks after sowing in the 2004-2006 wet seasons in a maize/cowpea intercropping system. There was no significant difference between the 2 crop arrangements with respect to the mean relative growth rate during 6-8 WAS in 2004 and 2005 but was significantly different in 2006. Inter-row crop arrangement produced a higher mean relative growth rate than intra-row crop arrangement. The combined data also showed that inter-row arrangement had higher mean relative growth rate than the intra-row arrangement. There were significant differences among the 4 crop proportions with respect to mean relative growth rate value in 2004-2006. In each of the wet season (2004-2006), the $3 \mathrm{C}: 1 \mathrm{M}$ crop proportion had significantly higher mean relative growth rate than the other proportions, though it was at par with the $1 \mathrm{C}: 1 \mathrm{M}$ proportion in 2004. Both $2 \mathrm{C}: 2 \mathrm{M}$ and $1 \mathrm{C}: 1 \mathrm{M}$ had similar mean relative growth rates except in 2005 when the $2 \mathrm{C}: 2 \mathrm{M}$ proportion produced a higher RGR. The 1C:3M proportion produced the least mean relative growth rate value each year with the exception of 2004 when it was at par with the $2 \mathrm{C}: 2 \mathrm{M}$ and 1C:1M proportions. The pooled data showed that the 3C:1M proportion produced higher mean relative growth rate that was higher than those for the other crop proportions which were at par (Table 1). There was significant difference between the 2 different row arrangements. The single-row arrangement had a significantly higher mean relative growth rate than the paired-row arrangement in each of the 3 years (2004-2006). The combined data did show that the single-row arrangement produced a significantly higher mean relative growth rate.

The values for maize mean relative growth rate during 8-10 WAS showed that there were significant differences among plant arrangements in 2005 and 2006 but not in 2004 (Table 2). The intra-row crop arrangement produced an RGR value that was significantly higher than the interrow arrangement in 2005 while the reverse was true for 2006. The combined data showed no significant difference between the 2 crop arrangements. There were significant differences in mean relative growth rates among the various crop proportions in 2004 and 2005 . The $2 \mathrm{C}: 2 \mathrm{M}$ proportion produced significantly higher RGR values than
Table 1: Effect of crop arrangement, crop proportion and row arrangement on mean relative growth rate $(\mathrm{g} / \mathrm{g} /$ week $)$ of maize 6-8 WAS in 20042006 wet seasons in a maize/cowpea intercropping system at Samaru, Nigeria

\begin{tabular}{|c|c|c|c|c|}
\hline \multirow[b]{2}{*}{ Treatments } & \multicolumn{3}{|l|}{ Years } & \multirow[b]{2}{*}{ Combined } \\
\hline & 2004 & 2005 & 2006 & \\
\hline \multicolumn{5}{|c|}{ Crop arrangement } \\
\hline Intra-row & 0.160 & 0.230 & $0.230^{b}$ & $0.210^{b}$ \\
\hline Inter-row & 0.160 & 0.280 & $0.270^{\mathrm{a}}$ & $0.240^{\mathrm{a}}$ \\
\hline $\mathrm{SE} \pm$ & 0.013 & 0.007 & 0.004 & 0.005 \\
\hline \multicolumn{5}{|c|}{ Crop proportion } \\
\hline $1 \mathrm{C}: 1 \mathrm{M}$ & $0.170^{\mathrm{ab}}$ & $0.220^{c}$ & $0.240^{b}$ & $0.210^{b}$ \\
\hline $3 \mathrm{C}: 1 \mathrm{M}$ & $0.210^{\mathrm{a}}$ & $0.330^{\mathrm{a}}$ & $0.290^{\mathrm{a}}$ & $0.280^{\mathrm{a}}$ \\
\hline $1 \mathrm{C}: 3 \mathrm{M}$ & $0.150^{b}$ & $0.220^{c}$ & $0.220^{c}$ & $0.200^{b}$ \\
\hline $2 \mathrm{C}: 2 \mathrm{M}$ & $0.130^{b}$ & $0.260^{b}$ & $0.240^{b}$ & $0.210^{b}$ \\
\hline $\mathrm{SE} \pm$ & 0.071 & 0.010 & 0.006 & 0.022 \\
\hline \multicolumn{5}{|c|}{ Row arrangement } \\
\hline Single-row & $0.190^{\mathrm{a}}$ & $0.280^{\mathrm{a}}$ & $0.280^{\mathrm{a}}$ & $0.250^{\mathrm{a}}$ \\
\hline Paired-row & $0.140^{b}$ & $0.230^{\mathrm{b}}$ & $0.230^{b}$ & $0.200^{b}$ \\
\hline $\mathrm{SE} \pm$ & 0.012 & 0.007 & 0.004 & 0.005 \\
\hline
\end{tabular}

Table 2: Effect of crop arrangement, crop proportion and row arrangement on mean relative growth rate $(\mathrm{g} / \mathrm{g} /$ week $)$ of maize $8-10$ WAS in 20042006 wet seasons in a maize/cowpea intercropping system at Samaru, Nigeria

\begin{tabular}{lcccc}
\hline & Years & & & \\
& -1 & & \\
Treatments & 2004 & 2005 & 2006 & Combined \\
\hline Crop arrangement & & & & \\
Intra-row & 0.300 & $0.180^{\mathrm{a}}$ & $0.210^{\mathrm{b}}$ & 0.230 \\
Inter-row & 0.290 & $0.090^{\mathrm{b}}$ & $0.260^{\mathrm{a}}$ & 0.210 \\
SE \pm & 0.016 & 0.008 & 0.007 & 0.007 \\
Crop prop ortion & & & & \\
1C:1M & $0.270^{\mathrm{b}}$ & $0.160^{\mathrm{a}}$ & 0.240 & $0.220^{\mathrm{a}}$ \\
3C:1M & $0.270^{\mathrm{b}}$ & $0.090^{\mathrm{c}}$ & 0.220 & $0.190^{\mathrm{b}}$ \\
1C:3M & $0.270^{\mathrm{b}}$ & $0.170^{\mathrm{a}}$ & 0.240 & $0.230^{\mathrm{a}}$ \\
2C:2M & $0.370^{\mathrm{a}}$ & $0.130^{\mathrm{b}}$ & 0.250 & $0.250^{\mathrm{a}}$ \\
SE \pm & 0.020 & 0.012 & 0.010 & 0.009 \\
Row arrangement & & & & \\
Single row & $0.340^{\mathrm{a}}$ & $0.160^{\mathrm{a}}$ & 0.240 & $0.250^{\mathrm{a}}$ \\
Paired row & $0.240^{\mathrm{b}}$ & $0.110^{\mathrm{b}}$ & 0.230 & $0.200^{\mathrm{b}}$ \\
SE \pm & 0.016 & 0.008 & 0.007 & 0.007 \\
\hline
\end{tabular}

Means within the same column followed by the same letter(s) are not significantly different at $5 \%$ probability level according to Duncan's Multiple Range Test (DMRT). C = Cowpea, $\mathrm{M}=$ Maize

the other proportions in 2004 while both $1 \mathrm{C}: 1 \mathrm{M}$ and $1 \mathrm{C}: 3 \mathrm{M}$ crop proportions had higher RGR values in 2005 . The least mean relative growth rate was obtained from $3 \mathrm{C}: 1 \mathrm{M}$ crop proportion. In 2006 , there was no significant difference in the mean relative growth rate for all the crop proportions. The combined data, however showed significant difference with the $3 \mathrm{C}: 1 \mathrm{M}$ proportion which had a lower mean relative growth rate while the other crop proportions were similar and had significantly higher RGR values (Table 2). Significant difference occurred between the 2 row arrangements in 2004 and 2005. In those 2 years, single-row arrangement produced higher mean relative growth rates than the paired-row arrangement. In 2006, both had similar mean relative growth rate. The combined data showed that a single-row arrangement had 
significantly higher mean relative growth rate values than the paired-row arrangement. The interactions between the treatment factors were not significant.

The mean relative growth rate of cowpea during 8-10 WAS as affected by crop arrangement, crop proportion and row arrangement in a maize/cowpea intercropping system is shown in Table 3. There was significant difference in mean RGR between the 2 plant arrangements in the 3 years. The inter-row crop arrangement gave significantly higher mean RGR than the intra-row arrangement in each of the 3 years. The combined data equally showed a similar trend where the inter-row crop arrangement produced cowpea plants with superior relative growth rate.

There were significant differences among the 4 crop proportions with respect to cowpea mean RGR in 2004 and 2006 but not in 2005 . In 2004 , only the $1 \mathrm{C}: 1 \mathrm{M}$ proportion had a significantly lower mean RGR value while the other crop proportions were at par. In 2006, both the $1 \mathrm{C}: 3 \mathrm{M}$ and 2C:2M crop proportions produced higher mean RGR in cowpea and were followed by the $3 \mathrm{C}: 1 \mathrm{M}$ crop proportion. The lowest mean RGR value was recorded in the case of the $1 \mathrm{C}: 1 \mathrm{M}$ crop proportion. There was significant difference between the 2 crop arrangements with respect to the mean cowpea RGR in 2005 and 2006. In those 2 years, the single row arrangement produced cowpea plants that had higher mean relative growth rates than the paired-row arrangement. The combined data showed that single-row arrangement was superior in cowpea plants with higher RGR. The interactions among the different treatment factors were not significant.

Crop growth rate: Table 4 shows maize crop growth rates during 6-8 of weeks after sowing in 2004-2006 as affected by crop arrangement, crop proportions and row arrangement in a maize/cowpea intercropping system. There was significant difference in the 2 crop arrangements on maize crop growth rate in 2005 and 2006. Inter-row crop arrangement produced maize plants with higher crop growth rates than intra-row arrangement in both years. It had a higher crop growth rate of $>16 \%$ in each year than the intra-row arrangement. The combined data for the period of experiment equally showed that inter-row arrangement was significantly higher in crop growth rate than intra-row crop arrangement. There were significant differences in crop growth rates of maize during 6-8 WAS among the 4 crop proportions in 2004-2006. In each year, 3C:1 M crop proportion produced maize crops with significantly higher crop growth rate than other crop proportions. This was followed by $2 \mathrm{C}: 2 \mathrm{M}$ and $1 \mathrm{C}: 1 \mathrm{M}$ crop proportions while $1 \mathrm{C}: 3 \mathrm{M}$ crop proportion produced the lowest crop growth rate in 2005 and 2006.
Table 3: Effect of crop arrangement, crop proportion and row arrangement on cowpea relative growth rate $\left(\mathrm{g} \mathrm{g}^{-1}\right.$.week $\left.{ }^{-1}\right)$ at 8-10 WAS during 2004-2006 wet season in a maize/cowpea intercropping system at Samaru, Nigeria

\begin{tabular}{|c|c|c|c|c|}
\hline \multirow[b]{2}{*}{ Treatments } & \multicolumn{3}{|l|}{ Years } & \multirow[b]{2}{*}{ Combined } \\
\hline & 2004 & 2005 & 2006 & \\
\hline \multicolumn{5}{|c|}{ Crop arrangement } \\
\hline Intra-row & $0.280^{b}$ & $0.660^{b}$ & $0.650^{b}$ & $0.510^{b}$ \\
\hline Inter-row & $0.650^{\mathrm{a}}$ & $0.900^{\mathrm{a}}$ & $0.800^{\mathrm{a}}$ & $0.780^{\mathrm{a}}$ \\
\hline $\mathrm{SE} \pm$ & 0.059 & 0.046 & 0.026 & 0.027 \\
\hline \multicolumn{5}{|c|}{ Crop proportion } \\
\hline $1 \mathrm{C}: 1 \mathrm{M}$ & $0.260^{c}$ & $0.670^{\mathrm{a}}$ & $0.570^{c}$ & $0.510^{b}$ \\
\hline $3 \mathrm{C}: 1 \mathrm{M}$ & $0.600^{\mathrm{a}}$ & $0.870^{\mathrm{a}}$ & $0.700^{\mathrm{b}}$ & $0.730^{\mathrm{a}}$ \\
\hline $1 \mathrm{C}: 3 \mathrm{M}$ & $0.410^{\mathrm{ab}}$ & $0.850^{\mathrm{a}}$ & $0.830^{\mathrm{a}}$ & $0.700^{\mathrm{a}}$ \\
\hline $2 \mathrm{C}: 2 \mathrm{M}$ & $0.590^{\mathrm{a}}$ & $0.680^{\mathrm{a}}$ & $0.780^{\mathrm{ab}}$ & $0.690^{\mathrm{a}}$ \\
\hline $\mathrm{SE} \pm$ & 0.083 & 0.065 & 0.037 & 0.037 \\
\hline \multicolumn{5}{|c|}{ Row arrangement } \\
\hline Single row & $0.500^{\mathrm{a}}$ & $0.850^{\mathrm{a}}$ & $0.790^{\mathrm{a}}$ & $0.710^{\mathrm{a}}$ \\
\hline Paired row & $0.440^{\mathrm{a}}$ & $0.690^{\mathrm{b}}$ & $0.650^{\mathrm{b}}$ & $0.590^{b}$ \\
\hline$\underline{\mathrm{SE} \pm}$ & 0.059 & 0.046 & 0.026 & 0.027 \\
\hline
\end{tabular}

Table 4: Effect of crop arrangement, crop proportion and row arrangement on maize mean crop growth rate ( $\mathrm{g} / \mathrm{m}^{2} /$ week) during 6-8 WAS in 2004-2006 wet seasons in a maize/cowpea intercropping sy stem at Samaru, Nigeria

\begin{tabular}{|c|c|c|c|c|}
\hline \multirow[b]{2}{*}{ Treatments } & \multicolumn{3}{|l|}{ Years } & \multirow[b]{2}{*}{ Combined } \\
\hline & 2004 & 2005 & 2006 & \\
\hline \multicolumn{5}{|c|}{ Crop arrangement } \\
\hline Intra-row & 11.50 & $15.70^{b}$ & $15.90^{\circ}$ & $14.40^{\mathrm{b}}$ \\
\hline Inter-row & 12.10 & $18.70^{\mathrm{a}}$ & $19.00^{\mathrm{a}}$ & $16.60^{\mathrm{a}}$ \\
\hline $\mathrm{SE} \pm$ & 0.78 & 0.34 & 0.25 & 0.29 \\
\hline \multicolumn{5}{|c|}{ Crop proportion } \\
\hline $1 \mathrm{C}: 1 \mathrm{M}$ & $11.30^{\circ}$ & $14.80^{\circ}$ & $16.70^{\circ}$ & $14.30^{b}$ \\
\hline $3 \mathrm{C}: 1 \mathrm{M}$ & $15.10^{\mathrm{a}}$ & $22.10^{\mathrm{a}}$ & $20.80^{\mathrm{a}}$ & $19.30^{\mathrm{a}}$ \\
\hline $1 \mathrm{C}: 3 \mathrm{M}$ & $10.80^{\circ}$ & $14.70^{\circ}$ & $15.40^{c}$ & $13.00^{b}$ \\
\hline $2 \mathrm{C}: 2 \mathrm{M}$ & $10.10^{\circ}$ & $17.20^{b}$ & $17.00^{\circ}$ & $14.80^{b}$ \\
\hline $\mathrm{SE} \pm$ & 1.10 & 0.48 & 0.36 & 0.41 \\
\hline \multicolumn{5}{|c|}{ Row arrangement } \\
\hline Single row & 12.90 & $19.20^{\mathrm{a}}$ & $19.50^{\mathrm{a}}$ & $17.20^{\mathrm{a}}$ \\
\hline Paired row & 10.80 & $15.20^{b}$ & $15.40^{b}$ & $13.80^{\mathrm{b}}$ \\
\hline $\mathrm{SE} \pm$ & 0.78 & 0.34 & 0.25 & 0.29 \\
\hline
\end{tabular}

Means within the same column followed by the same letter(s) are not significantly different at 5\% probability level according to Duncan's Multiple Range Test (DMRT). C = Cowpea, $\mathrm{M}=$ Maize

The combined data for the 3 years showed that the $3 \mathrm{C}: 1 \mathrm{M}$ crop proportion produced the highest crop growth rate than did others which were at par.

There was no significant difference between the 2 row arrangements in maize crop growth rate in 2004. However, significant differences existed in 2005 and 2006. In those 2 years, the single-row arrangement produced maize plants with higher crop growth rate than paired-row arrangement. The combined data for the period also showed that single row arrangement was statistically better in maize crop growth rate (Table 4).

The effects of crop arrangement, crop proportion and row arrangement on maize crop growth rate during 8-10 WAS in 2004-2006 are shown in Table 5. There were no significant differences in maize crop growth rate between 
Res. J. Agron., 6(1): 13-19, 2012

Table 5: Effect of crop arrangement, crop proportion and row arrangement on maize mean crop growth rate ( $\mathrm{g} / \mathrm{m}^{2} /$ week) during 8-10 WAS in 2004-2006 wet seasons and combined in a maize/cowpea intercropping system at Samaru, Nigeria

\begin{tabular}{|c|c|c|c|c|}
\hline \multirow[b]{2}{*}{ Treatments } & \multicolumn{3}{|l|}{ Years } & \multirow[b]{2}{*}{ Combined } \\
\hline & 2004 & 2005 & 2006 & \\
\hline \multicolumn{5}{|c|}{ Crop arrangement } \\
\hline Intra-row & 28.20 & 17.00 & $21.80^{\mathrm{b}}$ & 22.30 \\
\hline Inter-row & 29.20 & 19.80 & $27.50^{\mathrm{a}}$ & 22.20 \\
\hline $\mathrm{SE} \pm$ & 1.36 & 0.81 & 0.71 & 0.58 \\
\hline \multicolumn{5}{|c|}{ Crop proportion } \\
\hline $1 \mathrm{C}: 1 \mathrm{M}$ & $24.30^{b}$ & $16.10^{\mathrm{a}}$ & 24.70 & $21.40^{b}$ \\
\hline $3 \mathrm{C}: 1 \mathrm{M}$ & $29.10^{b}$ & $10.00^{b}$ & 24.80 & $21.30^{b}$ \\
\hline $1 \mathrm{C}: 3 \mathrm{M}$ & $26.10^{b}$ & $15.50^{\mathrm{a}}$ & 23.50 & $21.70^{b}$ \\
\hline $2 \mathrm{C}: 2 \mathrm{M}$ & $35.40^{\mathrm{a}}$ & $12.90^{\mathrm{ab}}$ & 25.70 & $24.70^{\mathrm{a}}$ \\
\hline $\mathrm{SE} \pm$ & 1.92 & 1.51 & 1.01 & 0.81 \\
\hline \multicolumn{5}{|c|}{ Row arrangement } \\
\hline Single row & $32.20^{\mathrm{a}}$ & $16.30^{\mathrm{a}}$ & $26.10^{\mathrm{a}}$ & $24.90^{\mathrm{a}}$ \\
\hline Paired row & $25.30^{b}$ & $10.40^{b}$ & $23.20^{b}$ & $19.60^{b}$ \\
\hline $\mathrm{SE} \pm$ & 1.36 & 0.81 & 071.00 & 0.58 \\
\hline
\end{tabular}

Means within the same column followed by the same letter(s) are not significantly different at $5 \%$ probability level according to Duncan's Multiple Range Test (DMRT). $\mathrm{C}=$ Cowpea, $\mathrm{M}=$ Maize

the 2 crop arrangements in 2004 and 2005 but there was in 2006. In that year, the inter-row arrangement produced maize plants with higher crop growth rate than the intra-row arrangement. However, the combined data for the 3 years did not show any significant difference between the 2 crop arrangements with respect to maize crop growth rate. Although, there was no significant difference in maize crop growth rate among different crop proportions in 2006, the situations were different in 2004 and 2005 . In 2004 , it was the only $2 \mathrm{C}: 2 \mathrm{M}$ crop proportion that produced significantly higher CGR values than the others which were at par. In 2005 however, 3 of the crop proportions (2C:2M, 1C:1M and $1 \mathrm{C}: 3 \mathrm{M}$ ) had similar but higher crop growth values than the $3 \mathrm{C}: 1 \mathrm{M}$ crop proportion. The combined data for the 3 years showed that the $2 \mathrm{C}: 2 \mathrm{M}$ crop proportion produced significantly higher maize crop growth rates than the other crop proportions.

The effect of crop arrangement, crop proportion and row arrangement on cowpea CGR during 8-10 WAS in 2004-2006 wet seasons is shown in Table 6. There was significant difference between the 2 crop arrangements with regard to cowpea CGR. In the 3 years, the inter-row crop arrangement produced cowpea plants that had significantly higher CGR values than the within-row arrangement. The inter-row crop arrangement had 215, 214 and $140 \%$ higher cowpea CGR values than the within-row arrangement in 2004-2006, respectively. The combined data also revealed that on the average inter-row crop arrangement had $164 \%$ higher cowpea CGR relative to the intra-row arrangement.

Significant differences were also recorded among the 4 crop proportions. While both $1 \mathrm{C}: 3 \mathrm{M}$ and $2 \mathrm{C}: 2 \mathrm{M}$
Table 6: Effect of crop arrangement, crop proportion and row arrangement on cowpea crop growth rate ( $\mathrm{g} / \mathrm{m}^{2}$ week) during 8-10 WAS in 20042006 wet seasons and combined in a maize/cowpea intercropping system at Samaru, Nigeria

\begin{tabular}{|c|c|c|c|c|}
\hline \multirow[b]{2}{*}{ Treatments } & \multicolumn{3}{|l|}{ Years } & \multirow[b]{2}{*}{ Combined } \\
\hline & 2004 & 2005 & 2006 & \\
\hline \multicolumn{5}{|c|}{ Crop arrangement } \\
\hline Intra-row & $2.00^{\mathrm{b}}$ & $3.00^{b}$ & $4.00^{b}$ & $3.30^{\mathrm{b}}$ \\
\hline Inter-row & $6.30^{\mathrm{a}}$ & $10.20^{\mathrm{a}}$ & $9.60^{\mathrm{a}}$ & $8.70^{\mathrm{a}}$ \\
\hline $\mathrm{SE} \pm$ & 0.34 & 0.29 & 0.16 & 0.16 \\
\hline \multicolumn{5}{|c|}{ Crop proportion } \\
\hline $1 \mathrm{C}: 1 \mathrm{M}$ & $2.10^{c}$ & $5.30^{\circ}$ & $5.80^{\circ}$ & $4.40^{c}$ \\
\hline $3 \mathrm{C}: 1 \mathrm{M}$ & $3.70^{b}$ & $9.10^{\mathrm{a}}$ & $9.00^{\mathrm{a}}$ & $7.30^{\mathrm{a}}$ \\
\hline $1 \mathrm{C}: 3 \mathrm{M}$ & $5.50^{\mathrm{a}}$ & $5.80^{\circ}$ & $5.10^{\mathrm{d}}$ & $5.50^{\mathrm{b}}$ \\
\hline $2 \mathrm{C}: 2 \mathrm{M}$ & $5.40^{\mathrm{a}}$ & $7.80^{b}$ & $7.20^{b}$ & $6.80^{\mathrm{a}}$ \\
\hline $\mathrm{SE} \pm$ & 0.48 & 0.41 & 0.22 & 0.22 \\
\hline \multicolumn{5}{|c|}{ Row arrangement } \\
\hline Single row & 4.40 & $7.90^{\mathrm{a}}$ & $7.60^{\mathrm{a}}$ & $6.60^{\mathrm{a}}$ \\
\hline Paired row & 4.00 & $6.10^{b}$ & $6.00^{b}$ & $5.30^{b}$ \\
\hline$\underline{\mathrm{SE} \pm}$ & 0.34 & 0.29 & 0.16 & 0.16 \\
\hline
\end{tabular}

Means within the same column followed by the same letter(s) are not significantly different at $5 \%$ probability level according to Duncan's Multiple Range Test (DMRT). C = Cowpea, $\mathrm{M}=$ Maize

produced significantly higher cowpea CGR values in 2004 , the subsequent years showed that the $3 \mathrm{C}: 1 \mathrm{M}$ crop proportion was significantly higher than the other proportions. In 2005 and 2006 , only the $2 \mathrm{C}: 2 \mathrm{M}$ crop proportion produced cowpea plants that had CGRs that closely followed the $3 \mathrm{C}: 1 \mathrm{M}$ crop proportion. The $1: 1$ (cowpea; maize) crop proportion produced the lowest CGR cowpea values throughout the period of experimentation. The combined data also showed that both $3 \mathrm{C}: 1 \mathrm{M}$ and $2 \mathrm{C}: 2 \mathrm{M}$ crop proportions ranked significantly higher in CGR than both the $1 \mathrm{C}: 3 \mathrm{M}$ and $1 \mathrm{C}: 1 \mathrm{M}$ crop proportions which came second and third respectively in crop CGR.

Both row arrangements did not show any significant effect on cowpea CGR in 2004. However in 2005 and 2006, there was significant difference between the 2 row arrangements. In those years, the single-row arrangement produced cowpea plants with significantly higher CGR values than the paired-row arrangement. The combined data showed that the single-row was significantly better than the paired-row arrangement with respect to cowpea CGR. The interactions between the treatment factors were not significant.

The relative growth rate values for maize were significantly higher in most cases when grown under inter-row crop arrangement than under the intra-row arrangement. This observation may be attributed to the ability of maize plants having a wider area/space to grow and accumulate dry matter per unit area faster with the upper canopy positioned for a better light interception while its fibrous root system with no strong competition from the other intercrop in such an arrangement was able to spread widely to access more underground growth 
resources. This is in conformity with the findings of Mukhala et al. (1999) and Tsubo et al. (2004) who in their separate reports stated that maize forms relatively larger upper canopy structures compared to beans and the roots of maize grow to a greater depth than those of beans. Thus in a maize-bean intercropping system, maize is more competitive than beans and maize usually has higher relative growth rate and crop growth rate being $\mathrm{C}_{4}$ plant which has the capacity to grow faster.

Although, the crop growth rate values for maize in both intra and inter-row crop arrangements were statistically similar in some cases, the average crop growth rate values showed that inter-row crop arrangement was significantly higher in a number of cases. This could also be attributed to the crop plants in this arrangement having better access to growth resources than the ones available to crops grown under the intra-row arrangement. Expectedly too, as CGR determination entails a community of plants, an aggregate of individual plants growing luxuriantly will undoubtedly produce a higher CGR. That was the observation with respect to the inter-row crop arrangement. This is in agreement with the findings of Bedoussac and Justes (2011) where they compared most of the commonly used indices for evaluating species interactions and intercrop efficiency using durum wheat-winter pea intercrops as case study. In this present study, the companion crop in the intercrop, cowpea is in addition, not a nitrogen consuming crop and rather fixes its own nitrogen symbiotically in the soil. Thus, an arrangement that allows less competition for these growth resources will make the maize crop to grow well and produce higher dry matter as was observed with respect to the $3 \mathrm{C}: 1 \mathrm{M}$ crop proportion as determined through Crop Growth Rate (CGR) and Relative Growth Rate (RGR). This superiority was more evident in the former growth character than the latter at virtually every measurement interval. The higher growth rates observed for the $3 \mathrm{C}: 1 \mathrm{M}$ proportion and single row arrangement relative to the other crop proportions and the paired-row arrangement respectively could be ascribed to the lesser competition between 2 contiguous maize or cowpea plants. It could also be attributed to the ability of maize which is a $\mathrm{C}_{4}$ species to quickly respond to available resources, most especially when there is less competition while cowpea thrives well when the shading effect against solar radiation is less. Similar findings of Tsubo et al. (2004) stated that crop growth rate is generally higher in $\mathrm{C}_{4}$ plant species whereas beans are $\mathrm{C}_{3}$ plants; the former grows faster than beans and is more competitive. In a more recent finding, Moriri et al. (2010) averred that a higher plant density of 40,000 plants ha ${ }^{-1}$ compared to a lower density of 10-20,000 plant ha $^{-1}$ impacted negatively on the growth of the cowpea plant in a maize/cowpea intercropping system.

\section{CONCLUSION}

It was said that the rate of growth in relation to the productivity of maize/cowpea intercropping system could be determined by using the indices of relative growth rate and crop growth rate, especially at the later stages of growth of the crops. The crop arrangement, crop proportion and row arrangement have significant effect on both RGR and CGR of maize and cowpea intercrop. Inter-row arrangement, the $3 \mathrm{C}: 1 \mathrm{M}$ or $2 \mathrm{C}$ : $2 \mathrm{M}$ crop proportion and single row arrangement favoured both indices of growth.

\section{ACKNOWLEDGEMENTS}

The researcers wish to acknowledge the provision of research facilities for this investigation by the Department of Agronomy, Ahmadu Bello University, Zaria and the Institute for Agricultural Research, Samaru, Zaria.

\section{REFERENCES}

Arnon, I., 1992. Crop Production in Dry Regions, Volume II: Systematic Treatment of Principal Crops. Leonard Hill, London, UK.

Bedoussac, L. and E. Justes, 2011. A comparison of commodity use indices for evaluating species interactions and intercrop efficiency: Application to durum wheat-winter pea intercrops. Field Crops Res., 124: $25-36$.

Bichi, S.I., 1982. Position (past, present and future) of soybean among the oil seed crop of Nigeria. Proc. Natl. Meet. Niger. Soybean Sci., 2: 40-44.

Keating, B.A. and P.S. Carberry, 1993. Resource capture and use in intercropping: Solar radiation. Field Crop Res., 34: 273-301.

Keku, P.A.K., 1999. Major pests and diseases of cereals, legumes rubber and root crops in Nigeria. Proceedings of the FAO, FDA/NSS Course in Comprehensive Training in Seed Production, Processing and Storage and Marketing, March 19-30, 2001, Bambey, Senegal, pp: 102-110.

Kumar, V., V.B. Ogunlela and R.C. Yadav, 1987. Productivity of maize and associated intercrops in relation to bed configuration and planting pattern. Samaru J. Agric. Res., 5: 97-108.

Moriri, S., L.G. Owoeye and I.K. Mariga, 2010. Influence of component crop densities and planting patterns on maize production in dry land maize/cowpea intercropping systems. Afr. J. Agric. Res., 5: 1200-1207. 
Mukhala, E., J.M. de Jager, L.D. Van Rensburg and S. Walker, 1999. Benefits of intercropping maize (Zea mays) and beans (Phaseolus vulgaris). Nutr. Res., 19: 629-641.

Olufajo, O.O. and B.B. Singh, 2002. Advances in Cowpea Cropping System Research. In: Challenges and Opportunities for Enhancing Sustainable Cowpea Production, Fatokun, C.A., S.A. Tarawali, B.B. Singh, P.M. Karmewa and M. Tamo (Eds.). International Institute of Tropical Agriculture (IITA), Ibadan, Nigeria, ISBN: 9789781311994 , pp: 267-277.

Radford, D.J., 1967. Growth analysis formulae-their use and abuse. Crop Sci., 7: 171-175.

SAS, 2001. Statistical Analysis (SAS) User's Guide. SAS Institute, Cary, North Carolina, USA.
Santaella, M., P.A. Casqueno and A.M. de Ron, 1999. Yield and yield components from inter-cropping improved bush bean cultivars with maize. J. Agron. Crop Sci., 183: 263-269.

Snedecor, G.W. and W.G. Cochran, 1967. Statistical Methods. Iowa State University Press, Ames, Iowa, Pages: 593.

Steel, R.G., J.H. Torrie and D.A. Dickey, 1997. Principles and Procedures of Statistics: A Biometrical Approach. 3rd Edn., McGraw-Hill, Singapore.

Tsubo, M. and S. Walker, 2002. A model of radiation interception and use by a maize-bean intercrop canopy. Agric. For. Meteorol., 110: 203-215.

Tsubo, M., H.O. Ogindo and S. Walker, 2004. Yield evaluation of maize-bean intercropping in a semi-arid region of South Africa. Afr. Crop Sci. J., 12: 351-358. 